\title{
Customized Fertilizers for Enhancing Yield and Quality of Bitter Gourd
}

\author{
K.M. Sellamuthu ${ }^{1 *}$, D. Janaki ${ }^{2}$, R. Kaleeswari ${ }^{3}$ and P. Malathi ${ }^{3}$ \\ ${ }^{1}$ Department of Natural Resource Management, Horticultural College and Research Institute, Periyakulam, India \\ ${ }^{2}$ Department of Soil Science and Agricultural Chemistry, Anbil Dharmalingam Agricultural College and Research Institute, \\ Tiruchirapalli, India \\ ${ }^{3}$ Department of Soil Science and Agricultural Chemistry, Tamil Nadu Agricultural University, Coimbatore, India \\ *Corresponding author: kmsellamuthu@tnau.ac.in (ORCID ID: 0000-0002-2192-8030)
}

Paper No. 938

Received: 02-09-2021

Revised: 28-11-2021

Accepted: 06-12-2021

\begin{abstract}
Customized fertilizers are ready to apply multinutrient fertilizers to meet the specific nutritional requirement of a crop. Customized fertilizer with major nutrients alone and with micronutrients were prepared and evaluated on the growth, yield and quality of bitter gourd. Two field experiments were conducted at Horticultural College and Research Institute, Periyakulam, Tamil Nadu, India. The results revealed that application of $100 \% \mathrm{CFII}\left(\mathrm{T}_{7}\right)$ found to record the highest the vine length, primary branches/ vine, number of fruits/vine, fruit length, fruit yield per plant and fruit yield. Quality parameters of the fruits also revealed that ascorbic acid, TSS, Fe and Zn content were significantly higher in the treatment receiving application of $100 \%$ CFII with micronutrients. The results indicated that customized fertilizers with major and micronutrients through fertigation results in better growth, fruit yield and quality in bitter gourd.
\end{abstract}

\section{HIGHLIGHTS}

(0 Application of 100\% CFII (T7) found to record the highest the vine length, primary branches/vine, number of fruits/vine, fruit length, fruit yield per plant and fruit yield.

( Q Quality parameters of the fruits were significantly higher in the treatment receiving application of $100 \%$ CFII with micronutrients.

Keywords: Bitter gourd, customized fertilizers, yield and quality

Fertilizer is one of the key inputs in augmenting food grain production and it contribute towards 55 per cent of additional food grain production (Kaleeswari et al. 2013). The scope for extending the cultivable area is limited and hence enhancing the productivity in unit area is the only option and fertilizer is the main cart puller (Choudhary et al. 2020). Imbalanced application of fertilizers is a common problem across the country. The All India Coordinated Research Project on Micronutrients by the ICAR has shown widespread micronutrient deficiencies in India. A study revealed a wide variation in the concentrations of available $S$ and micronutrients in agricultural soils of India with per cent deficiency of available S (58.6\%), available
Zn (51.2\%), available B (44.7\%), available Fe (19.2\%), available $\mathrm{Cu}(1104 \%)$ and available $\mathrm{Mn}(17.4 \%)$ (Shukla et al. 2021).

The customized fertilizers may be of the combination of nutrients based on soil testing and requirement of a crop and the formulation may contain primary, secondary and micro nutrients. The FCO recognizes customized fertilizers importance and defined as: Multi-nutrient carriers designed to contain macro, secondary and/or micronutrient both from inorganic

How to cite this article: Sellamuthu, K.M., Janaki, D., Kaleeswari, R. and Malathi, P. 2021. Customized Fertilizers for Enhancing Yield and Quality of Bitter Gourd. Int. J. Ag. Env. Biotech., 14(04): 505-509.

Source of Support: None; Conflict of Interest: None क क 
sources and/or organic sources, manufactured through a systematic process of granulation, satisfying the crop's nutritional needs, specific to its site, soil and stage validated by a scientific crop model, capability developed by an accredited fertilizer manufacturing/marketing company (Rakshit et al. 2012). Customized fertilizer is a Tailor made multi- nutrient carrier to meet specific basal nutritional needs of a crop (Majumdar and Prakash 2018). Application of customized fertilizers promotes site specific nutrient management to achieve maximum use efficiency of applied nutrients with cost effectiveness (Kamble and Kathmale 2015). In India, there are about 36 customized formulations approved by fertilizer control order (Majumdar and Prakash 2018). Hence, customized fertilizers can help in improving the formulation for site specific, balanced fertilizer management strategies and also will be more advantageous compared to conventional, blanket and imbalanced fertilizer recommendation (Prakash et al. 2021).

\section{MATERIALS AND METHODS}

First field experiment was conducted during September 2019 - January 2020 with variety Co-1 bitter gourd and the second field experiment with Palee Hybrid during Rabi 2020 in the Western
Block, Horticultural College and Research Institute, Periyakulam, Tamil Nadu, India to study yield and qualityas influenced by graded levels of customized fertilizers. Initial soil samples were collected analyzed $\mathrm{pH}, \mathrm{EC}$, organic carbon, available, N, P and $\mathrm{K}, \mathrm{Ca}, \mathrm{Mg}$, $\mathrm{S}$ and micronutrients viz., DTPA- Fe, $\mathrm{Zn}, \mathrm{Mn}, \mathrm{Cu}$ and HWS-boron. The treatments were imposed as per the treatment schedule. Sowing was done with bitter gourd hybrid Palee and observations on biometrics, yield and its quality parameters were recorded.

The treatments include, $\mathrm{T}_{1}$ - Untreated control, $\mathrm{T}_{2}$ - Humic Acid( 62.51 ha- $\left.^{-1}\right), \mathrm{T}_{3}-75 \%$ CF I, $\mathrm{T}_{4}$ $-100 \%$ CF I, $\mathrm{T}_{5}-125 \%$ CF I, $\mathrm{T}_{6}-75 \%$ CF II, $\mathrm{T}_{7}$ $-100 \%$ CF II, $\mathrm{T}_{8}-125 \%$ CF II and $\mathrm{T}_{9}-100 \%$ RDF (as 19:19:19). Customized fertilizer were prepared on $\mathrm{N}$ equivalent basis to match the recommended dose of fertilizers for bitter gourd.CF- I consist of only macronutrients while CF- II contains macro and micronutrients. Recommended dose of fertilizer (RDF) for bitter gourd in Tamil Nadu is 200:100:100 kg N:P $\mathrm{O}_{5}: \mathrm{K}_{2} \mathrm{Oha}^{-1}$. Four splits of RDF as customized fertilizers was applied as per the recommended fertigation schedule. The fertilizers were applied through fertigation. The observations like length of vine, primary branches/vine, number of fruits/vine, fruit length, girth,fruit weight/vine,

Table 1: Initial soil properties of experimental site

\begin{tabular}{|c|c|c|c|c|}
\hline Particulars & Expt. I & Expt. II & Method & Reference \\
\hline $\mathrm{pH}$ & 7.42 & 7.65 & Potentiometry & Jackson (1973) \\
\hline $\mathrm{EC}\left(\mathrm{d} S \mathrm{~m}^{-1}\right)$ & 0.12 & 0.03 & Conductometry & Jackson (1973) \\
\hline Organic carbon $\left(\mathrm{g} \mathrm{kg}^{-1}\right)$ & 0.27 & 0.25 & Chromic acid wet digestion method & Walkley and Black (1934) \\
\hline Nitrogen $\left(\mathrm{kg} \mathrm{ha}^{-1}\right)$ & 210 & 266 & Extracted with $\mathrm{KMnO}_{4}$ and distilled & Subbiah and Asija (1956) \\
\hline Phosphorus (kg ha $\left.{ }^{-1}\right)$ & 18.5 & 21.0 & $\begin{array}{l}\text { Olsen's extraction method, } \\
\text { Spectrophotometry }\end{array}$ & Jackson (1973) \\
\hline Calcium (mg kg-1) & 540 & 640 & $\begin{array}{l}\mathrm{NH}_{4} \mathrm{OAc} \text { extractant method, Flame } \\
\text { photometry }\end{array}$ & Jackson (1973) \\
\hline Magnesium (mg kg-1) & 260 & 336 & $\begin{array}{l}\mathrm{NH}_{4} \mathrm{OAc} \text { extractant method, Flame } \\
\text { photometry }\end{array}$ & Jackson (1973) \\
\hline Sulphur (mg kg-1) & 14.8 & 15.8 & $\mathrm{CaCl}_{2}$ extractant method, Turbidimetry & Williams and Steinbergs (1959) \\
\hline Manganese $\left(\mathrm{mg} \mathrm{kg}^{-1}\right)$ & 5.24 & 3.35 & $\begin{array}{l}\text { DTPA extraction method, Atomic } \\
\text { Absorption spectrophotometry }\end{array}$ & Lindsay and Norvel (1978) \\
\hline Copper $\left(\mathrm{mg} \mathrm{kg}^{-1}\right)$ & 1.52 & 1.21 & $\begin{array}{l}\text { DTPA extraction method, Atomic } \\
\text { Absorption spectrophotometry }\end{array}$ & Lindsay and Norvel (1978) \\
\hline Boron (mg kg-1) & 1.60 & 1.69 & Hot water extraction & Berger and Troug (1944) \\
\hline
\end{tabular}


fruit yield, Brix and ascorbic acid, Fe and Zn content in fruits were recorded. Brix and ascorbic acid were estimated as per AOAC (2007). Plant samples were drawn, cleaned, dried at $70^{\circ} \mathrm{C}$ and powdered using Wiley mill and analysed for total Fe and Zn content (Jackson, 1973) and determined in AAS (Lindsay and Norvel, 1978).

\section{RESULTS AND DISCUSSION}

\section{Yield parameters}

The observations on vine length, number of primary branches, vine length number of fruits per vine, fruit length and fruit girth were recorded. The results from the first experiment revealed that application of $100 \%$ CFII $\left(\mathrm{T}_{7}\right)$ found to record the highest the vine length $(\mathrm{m})$ of $5.78 \mathrm{~m}$, primary branches/ vine (9.60), number of fruits/vine (28.50), fruit length of $37.0 \mathrm{~cm}$ and girth of $9.90 \mathrm{~cm}$ followed by $\mathrm{T}_{8^{\prime}} \mathrm{T}_{4^{\prime}} \mathrm{T}_{5}$ and $\mathrm{T}_{6}$ while the untreated control $\left(\mathrm{T}_{1}\right)$ recorded the lowest values in all these characters (Table 2 and 3 ).
In the second field experiment, application of $100 \%$ CFII $\left(\mathrm{T}_{8}\right)$ found to record the highest vine length (m) of $5.04 \mathrm{~m}$ while $100 \%$ CFII $\left(\mathrm{T}_{7}\right)$ recorded the highest no of primary branches/ vine (9.00) highest number of fruits/vine (27.6), fruit length $(35.7 \mathrm{~cm})$ and girth $(9.71 \mathrm{~cm})$ while the untreated control $\left(\mathrm{T}_{1}\right)$ recorded the lowest value of in all these characters (Table 2 and 3).

Mean data from the two field experiments indicated that length of vine varied from 3.11 to $5.32 \mathrm{~m}$ and the highest vine length was recorded in the treatment receiving application of $100 \%$ CFII $\left(\mathrm{T}_{7}\right)$. Number of primary branches ranged from 4.97 per plant in control to 9.30 per plant in $100 \%$ CFII $\left(\mathrm{T}_{7}\right)$. Number of fruits per plant varied from 15.44 to 28.03 and the highest was in $100 \%$ CFII $\left(\mathrm{T}_{7}\right)$. Mean fruit length varied from 24.8 to $36.4 \mathrm{~cm}$, fruit girth from 6.29 to $9.80 \mathrm{~cm}$ and single fruit weight from 89.1 to $130.3 \mathrm{~g}$. The highest value for fruit length, fruit girth and single fruit weight was recorded with the application of $100 \%$ CFII $\left(\mathrm{T}_{7}\right)$ (Table 2 and 3).

Table 2: Effect of customized fertilizers on length of vine, number of primary branches and fruits per plant

\begin{tabular}{|c|c|c|c|c|c|c|c|c|c|}
\hline \multirow{2}{*}{ Treatment } & \multicolumn{3}{|c|}{ Length of vine (m) } & \multicolumn{3}{|c|}{ Number of primary branches / plant } & \multicolumn{3}{|c|}{ Number of fruits/ plant } \\
\hline & Expt. I & Expt. II & Pooled Mean & Expt. I & Expt. II & Pooled Mean & Expt. I & Expt. II & Pooled Mean \\
\hline $\mathrm{T} 1$ & 3.54 & 2.68 & 3.11 & 6.50 & 3.44 & 4.97 & 18.0 & 12.9 & 15.44 \\
\hline $\mathrm{T} 2$ & 3.85 & 2.95 & 3.40 & 7.00 & 5.22 & 6.11 & 22.0 & 16.8 & 19.39 \\
\hline T3 & 4.32 & 3.53 & 3.93 & 7.70 & 6.44 & 7.07 & 23.0 & 20.6 & 21.78 \\
\hline $\mathrm{T} 4$ & 4.56 & 4.05 & 4.30 & 8.10 & 7.67 & 7.88 & 26.0 & 24.2 & 25.11 \\
\hline T5 & 4.39 & 4.25 & 4.32 & 7.90 & 7.22 & 7.56 & 24.5 & 23.8 & 24.14 \\
\hline T7 & 5.78 & 4.87 & 5.32 & 9.60 & 9.00 & 9.30 & 28.5 & 27.6 & 28.03 \\
\hline T8 & 5.52 & 5.04 & 5.28 & 9.40 & 8.89 & 9.14 & 27.6 & 27.1 & 27.36 \\
\hline T9 & 4.28 & 3.72 & 4.00 & 8.00 & 6.78 & 7.39 & 20.0 & 21.9 & 20.94 \\
\hline SEd & 0.24 & 0.06 & & 0.14 & 0.26 & & 0.48 & 0.35 & \\
\hline $\mathrm{CD}$ & 0.51 & 0.12 & & 0.30 & 0.54 & & 1.04 & 0.74 & \\
\hline
\end{tabular}

Table 3: Effect of customized fertilizers on fruit length, fruit girth single fruit weight

\begin{tabular}{|c|c|c|c|c|c|c|c|c|c|}
\hline \multirow{2}{*}{ Treatment } & \multicolumn{3}{|c|}{ Fruit length $(\mathrm{cm})$} & \multicolumn{3}{|c|}{ Fruit girth $(\mathrm{cm})$} & \multicolumn{3}{|c|}{ Single fruit weight (g) } \\
\hline & Expt. I & Expt. II & Pooled Mean & Expt. I & Expt. II & Pooled Mean & Expt. I & Expt. II & Pooled Mean \\
\hline $\mathrm{T} 1$ & 26.1 & 23.5 & 24.8 & 7.00 & 5.59 & 6.29 & 72.2 & 106.1 & 89.1 \\
\hline $\mathrm{T} 2$ & 28.5 & 30.0 & 29.2 & 7.80 & 7.28 & 7.54 & 81.8 & 113.7 & 97.7 \\
\hline T3 & 29.5 & 31.0 & 30.3 & 7.90 & 8.12 & 8.01 & 95.7 & 132.8 & 114.2 \\
\hline $\mathrm{T} 4$ & 32.8 & 34.0 & 33.4 & 8.50 & 9.09 & 8.80 & 92.3 & 140.7 & 116.5 \\
\hline T5 & 32.5 & 33.4 & 32.9 & 8.20 & 9.02 & 8.61 & 114.3 & 139.0 & 126.6 \\
\hline T6 & 35.2 & 33.0 & 34.1 & 9.20 & 8.93 & 9.07 & 107.9 & 139.6 & 123.7 \\
\hline T7 & 37.0 & 35.7 & 36.4 & 9.90 & 9.71 & 9.80 & 112.3 & 148.4 & 130.3 \\
\hline T8 & 36.4 & 35.6 & 36.0 & 9.60 & 9.66 & 9.63 & 112.3 & 145.8 & 129.0 \\
\hline T9 & 27.2 & 32.1 & 29.6 & 7.30 & 8.53 & 7.92 & 100.0 & 134.7 & 117.3 \\
\hline SEd & 0.53 & 0.68 & & 0.13 & 0.32 & & 0.49 & 2.78 & \\
\hline CD & 1.15 & 1.44 & & 0.28 & 0.69 & & 1.04 & 5.90 & \\
\hline
\end{tabular}


Combined application of NPK and micronutrients as customized fertilizer might have increased the yield parameters by enhancing the use efficiency of major nutrients by the micronutrients. This was evident from Bharati et al. (2018). To enhance the productivity of bitter gourd, balanced use of macro as well as micronutrients together with better management practices for the improvement in the availability of nutrients are highly essential.

\section{YIELD AND QUALITY PARAMETERS}

\section{Fruit yield}

Results on fruit yield from the field experiment-I revealed that application of $100 \%$ CFII $\left(\mathrm{T}_{7}\right)$ found to record the highest the fruit weight/vine $(3.2 \mathrm{~kg})$ and fruit yield $\left(24.60 \mathrm{t} \mathrm{ha}^{-1}\right)$. Similarly in the second experiment, application of $100 \%$ CFII $\left(\mathrm{T}_{7}\right)$ found to record the highest fruit weight/vine $(3.20 \mathrm{~kg})$ and fruit yield $\left(24.60 \mathrm{t} \mathrm{ha}^{-1}\right)$. Mean fruit yield per plant varied from 2.31 to $5.57 \mathrm{~kg}$ per plant and the highest was recorded in $100 \%$ CF II $\left(\mathrm{T}_{7}\right)$. Mean fruit yield ranged from 12.3 to $25.7 \mathrm{t} \mathrm{ha}^{-1}$ and the highest was recorded in the treatment receiving application of 100\% CFII $\left(\mathrm{T}_{7}\right)$ (Table 4).

Micronutrients are important for growth, yield, fruit setting, post-harvest life of crops and resistance development against stresses. But now in Indian soils, along with the single nutrient deficiency, deficiencies of two or more nutrients were prevalent in different states of India (Shukla et al. 2021). Hence, combining micronutrient along with the primary and secondary nutrients are essential to get higher yield and better fruit quality. Enhancement of yield of bitter gourd with micronutrients was observed by Ashraf et al. (2020).

\section{Fruit Quality}

In the experiment-I, the highest values of Ascorbic acid (120.30 mg/100g), TSS(4.88 Brix), Fe (432 ppm) and $\mathrm{Zn}(78 \mathrm{ppm})$ were recorded in the treatment receiving application of $100 \%$ CFII $\left(\mathrm{T}_{7}\right)$ and it was followed by $\mathrm{T}_{8}$ while the untreated control $\left(\mathrm{T}_{1}\right)$ recorded the lowest level of Ascorbic acid content (98.50 mg/100g), TSS (3.54 Brix), Fe (311ppm) and $\mathrm{Zn}$ (40 ppm) (Table 4). Quality parameters from the experiment-II also revealed that Ascorbic acid (111.4

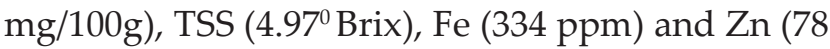
ppm) were significantly higher in the treatment receiving application of $100 \%$ CFII $\left(\mathrm{T}_{7}\right)$ followed by $\mathrm{T}_{8}$ while the untreated control $\left(\mathrm{T}_{1}\right)$ recorded the lowest value of Ascorbic acid ( $83.1 \mathrm{mg} / 100 \mathrm{~g}$ ), TSS (2.93 ${ }^{\circ}$ Brix), Fe (298 ppm) and Zn (47.8 ppm) in all these characters (Table 5).

Mean data of the two experiments indicated that Ascorbic acid, TSS, Fe and Zn content varied from 90.8 to $115.8 \mathrm{mg} / 100 \mathrm{~g}, 3.24$ to $4.92 \mathrm{O}^{\prime}$ brix, 305 to $382 \mathrm{ppm}$ and 43.9 to $68.6 \mathrm{ppm}$ respectively. Application of major and micro nutrients as customized formulation found to enhance the quality parameters of bitter gourd. Kamble and Kathmale (2015) observed that customised fertilizers improved the yield and quality parameters of onion. Ashraf et al. (2020) also found that combination of micronutrients gave good results regarding quality attributes of bitter gourd.

Table 4: Effect of customized fertilizers on fruit yield per plant and fruit yield

\begin{tabular}{lllllll}
\hline \multirow{2}{*}{ Treatment } & \multicolumn{3}{c}{ Fruit yield per plant $\mathbf{( k g})$} & \multicolumn{3}{c}{ Fruit yield $\left(\mathbf{t} \mathbf{~ h a}^{\mathbf{1}}\right)$} \\
\cline { 2 - 7 } & Expt. I & Expt. II & Pooled Mean & Expt. I & Expt. II & Pooled Mean \\
\hline T1 & 1.30 & 3.32 & 2.31 & 13.5 & 11.1 & 12.3 \\
T2 & 1.80 & 4.88 & 3.34 & 15.5 & 16.3 & 15.9 \\
T3 & 2.20 & 5.78 & 3.99 & 17.5 & 19.3 & 18.4 \\
T4 & 2.40 & 6.84 & 4.62 & 19.5 & 22.8 & 21.1 \\
T5 & 2.80 & 6.75 & 4.78 & 20.3 & 22.5 & 21.4 \\
T6 & 3.00 & 7.16 & 5.08 & 21.5 & 23.9 & 22.7 \\
T7 & 3.20 & 8.06 & 5.63 & 24.6 & 26.9 & 25.7 \\
T8 & 3.10 & 8.04 & 5.57 & 22.4 & 26.8 & 24.6 \\
T9 & 2.00 & 6.17 & 4.08 & 18.5 & 20.6 & 19.5 \\
\hline SEd & 0.09 & 0.13 & & 0.45 & 0.43 & \\
\hline CD & 0.18 & 0.27 & 0.97 & 0.91 & \\
\hline
\end{tabular}


Table 5: Effect of customized fertilizers on fruit quality of bitter gourd

\begin{tabular}{|c|c|c|c|c|c|c|c|c|c|c|c|c|}
\hline \multirow{2}{*}{ Treatment } & \multicolumn{3}{|c|}{$\begin{array}{l}\text { Ascorbic acid content in } \\
\text { fruit }(\mathrm{mg} / 100 \mathrm{~g})\end{array}$} & \multicolumn{3}{|c|}{$\begin{array}{l}\text { TSS content in fruit } \\
\left(\mathrm{O}^{\prime} \text { brix }\right)\end{array}$} & \multicolumn{3}{|c|}{ Fe content in fruit (ppm) } & \multicolumn{3}{|c|}{ Zn content in fruit (ppm } \\
\hline & Expt. I & Expt. II & $\begin{array}{l}\text { Pooled } \\
\text { Mean }\end{array}$ & Expt. I & Expt. II & $\begin{array}{l}\text { Pooled } \\
\text { Mean }\end{array}$ & Expt. & I Expt. II & $\begin{array}{l}\text { Pooled } \\
\text { Mean }\end{array}$ & Expt. I & Expt. II & $\begin{array}{l}\text { Pooled } \\
\text { Mean }\end{array}$ \\
\hline $\mathrm{T} 1$ & 98.5 & 83.1 & 90.8 & 3.54 & 2.93 & 3.24 & 311 & 298 & 305 & 40.0 & 47.8 & 43.9 \\
\hline $\mathrm{T} 2$ & 103.4 & 93.8 & 98.6 & 3.62 & 3.20 & 3.41 & 321 & 304 & 313 & 45.0 & 52.4 & 48.7 \\
\hline T3 & 108.5 & 98.1 & 103.3 & 4.02 & 4.17 & 4.09 & 342 & 316 & 329 & 52.0 & 54.4 & 53.2 \\
\hline $\mathrm{T} 4$ & 112.3 & 104.0 & 108.2 & 4.32 & 4.63 & 4.48 & 356 & 324 & 340 & 65.0 & 56.2 & 60.6 \\
\hline T5 & 113.1 & 102.4 & 107.8 & 4.40 & 4.40 & 4.40 & 382 & 326 & 354 & 66.0 & 56.4 & 61.2 \\
\hline T6 & 116.1 & 104.3 & 110.2 & 4.52 & 4.53 & 4.53 & 410 & 326 & 368 & 72.0 & 57.6 & 64.8 \\
\hline $\mathrm{T} 7$ & 120.3 & 111.4 & 115.8 & 4.88 & 4.97 & 4.92 & 432 & 332 & 382 & 78.0 & 59.2 & 68.6 \\
\hline $\mathrm{T} 8$ & 118.3 & 110.1 & 114.2 & 4.68 & 4.77 & 4.72 & 422 & 334 & 378 & 74.0 & 59.8 & 66.9 \\
\hline T9 & 110.5 & 100.0 & 105.3 & 4.22 & 4.27 & 4.24 & 356 & 324 & 340 & 65.0 & 56.4 & 60.7 \\
\hline SEd & 0.92 & 1.25 & & 0.06 & 0.14 & & 5.7 & 1.42 & & 1.74 & 0.26 & \\
\hline CD & 1.97 & 2.66 & & 0.13 & 0.29 & & 12.3 & 3.01 & & 3.73 & 0.55 & \\
\hline
\end{tabular}

\section{CONCLUSION}

The results from the two field experiments revealed that application of $100 \%$ CFII $\left(\mathrm{T}_{7}\right)$ found to record the highest the vine length, primary branches/vine, number of fruits/vine, fruit length, fruit yield per plant, fruit yield. Quality parameters also revealed that ascorbic acid, TSS, Fe and Zn content were significantly higher in the treatment receiving application of $100 \%$ CFII $\left(\mathrm{T}_{7}\right)$. The results revealed that application customized fertilizers as major and micronutrients through fertigation results in higher growth, fruit yield and quality parameters of bitter gourd.

\section{REFERENCES}

AOAC. 2007. Official methods of Analysis. $18^{\text {th }}$ Edition. Association of Official Analytical Chemists. Washington DC.

Ashraf, M.I, Liaqat, B., Shahzadi, K., Kiran, S., Anam, L., Shaukat, M.B., Hussain, N. 2020. Effect of zinc, iron and boron on growth, yield and quality of Bitter gourd (Momordica charantia L.) in Punjab. Int. J. Agron. and Agri. Res., 16(4): 11-19.

Berger, K.C. and Troug, E. 1944. Boron test and determination for soils and plants. Soil Sci., 57: 25 - 26.

Bharati, D.K., Verma, R.B., Singh, V.K., Kumar, R., Sinha, S. and S.K. Sinha. 2018. Response of Bitter Gourd (Momordica charantia L.) to Foliar Feeding of Micronutrient on the Growth, Yield and Quality. Int. J. Curr. Microb. and Appl. Sci., 7(2): 2341-2346.

Choudhary, S.K., Kumar, R., Kumar, A. and Ranjan, R.D. 2020. Customized Fertilizers- All in One a Review. Int. Res. J. Pure Appl. Chem., 21(9): 27-39.

Kaleeswari, R.N. 2013. Impact of customized fertilizers on yield and soil properties of lowland rice ecosystem. Madras Agric. J., 100(3): 150- 152.

Kamble, B.M. and Kathmale, D.K. 2015. Effect of different levels of customized fertilizer on soil nutrient availability, yield and economics of onion. J. Appl. and Nat. Sci., 7(2): 817-21.

Lindsay, N.L. and Norvell, W.A. 1978. Development of DTPA soil test for zinc, iron, manganese and copper. Soil Sc. Soc. of America J., 42: 421-428.

Majumdar, S. and Prakash, N.B. 2018. Prospects of customised fertilizers in Indian agriculture. Curr. Sci., 115 (2): 242-248.

Olsen, S.R., Cole, C.V., Watanabe, P.S. and Dean, L.A. 1954. Estimation of available phosphorus in soils by extraction with sodium bicarbonate. U.S.D.A. Circ., 939.

Prakash, N.B., Shruthi, Mallikarjuna L., Kadalli, G.G. and Sujith, G.M. 2021. Nutrient requirement and use efficiency of rice (Oryza sativa L.) as influenced by graded levels of customized fertilizer. J. Plant Nutri., 44(19): 2897-2911.

Rakshit, R., Rakshit, A. and Das, A. 2012. Customized fertilizers: Marker in fertilizer revolution. Int. J. Agri. and Environ. Biotech., 5(1): 67-75.

Subbiah, B.V. and Asija, G.L. 1956. A rapid procedure for estimation of available nitrogen in soils. Curr. Sci., 25: 259-260.

Shukla, A.K., Behera, S.K., Prakash, C., Patra, A.K., Rao, C.S., Chaudhari, S.K., Das, S., Singh, A.K. and Green, A. 2021.Assessing Multi-Micronutrients Deficiency in Agricultural Soils of India. Sustainability, 13(9136): 1-19.

Stanford, S. and English, L. 1949. Use of Flame photometer in rapid soil test for K and Ca. Agro. J., 41: 446-447.

Walkley, A. and Black, I.A. 1934. An examination of soil organic carbon by chromic acid titration method. Soil Sci., 37: 29.

Williams, C.H. and Steinberg, H. 1959. Soil sulphur fractions as chemical indices of available sulphur in some Australian soils. Australian J. Agric. Res., 10: 340-352. 
